\title{
Thrombin receptor expression in rheumatoid and osteoarthritic synovial tissue
}

\author{
Ruth Morris, Paul G Winyard, Lawrence F Brass, David R Blake, Christopher J Morris
}

\begin{abstract}
Objective-To investigate the possibility that synovial cells might respond to thrombin in the inflamed human joint, using immunohistochemical detection of thrombin receptors.

Methods-Frozen sections of synovial membrane from 20 patients with rheumatoid arthritis, 16 with osteoarthritis, and four normal controls were stained using a monoclonal antibody to the human thrombin receptor. Sections were also double stained for both receptors and non-specific esterase.

Results-Receptor positive cells were present in rheumatoid synovia, with some cells also staining positively for nonspecific esterase. In contrast, both osteoarthritic and normal synovia contained very few cells expressing receptors. Conclusions-Thrombin may mediate important pathological changes during chronic inflammatory joint disease.
\end{abstract}

(Ann Rheum Dis 1996;55:841-843)

Fibrin formation is catalysed by thrombin, a serine protease that can also cause a range of cellular responses linked to inflammation and healing. Low levels of thrombin are chemotactic for monocytes, ${ }^{1}$ stimulate proliferation in a variety of cells including fibroblasts, ${ }^{2}$ and increase vascular permeability through the contraction of endothelial cells. ${ }^{3}$ These cellular effects are mainly initiated through a transmembrane receptor originally characterised in human platelets. ${ }^{4}$ Thrombin is thought to cleave the receptor at a site within its extracellular N-terminal region. This results in the creation of a new $\mathrm{N}$-terminus, which then acts as the ligand for receptor activation. Peptide agonists comprising the final 14 amino acids of this new N-terminus mimic the effects of thrombin on fibroblasts and other cell types in vitro. ${ }^{5}$

Rheumatoid arthritis is a chronic inflammatory disease in which widespread synovial fibrin deposition is a prominent feature. ${ }^{6}$ Thrombin may enter the rheumatoid synovium due to inflammatory changes in vascular permeability, or alternatively macrophages appear able to generate thrombin in situ. ${ }^{7}$ The in vitro findings described above suggest that thrombin could be influential in mediating certain key pathological changes in rheumatoid arthritis. These include the recruitment of mononuclear phagocytes into joint tissues and proliferation of synovial fibroblast-like cells. We have therefore examined the possibility that synovial cells are being activated by thrombin. We used a monoclonal antibody directed against a specific region within the $\mathrm{N}$-terminus of the cleaved thrombin receptor. ${ }^{8}$

\section{Methods}

SYNOVIAL TISSUES

Specimens of synovial tissue from 20 patients with rheumatoid arthritis and 16 with osteoarthritis were collected at knee or hip joint replacement surgery. Rheumatoid arthritis patients had definite classical disease as defined by American College of Rheumatology (1987) criteria and were receiving standard anti-inflammatory drug treatment before arthroplasty. Additionally, synovial tissue was obtained at necropsy from the knee joint of four control subjects with no history of arthritis. The synovial tissues were dissected into 3-5 $\mathrm{mm}$ pieces, snap frozen in melting isopentane, and stored at $-70^{\circ} \mathrm{C}$ before use. Frozen $5 \mu \mathrm{m}$ sections were cut at $-30^{\circ} \mathrm{C}$ and mounted on poly-L-lysine coated slides. The sections were stained immediately.

\section{IMMUNOHISTOCHEMISTRY}

The monoclonal antibody ATAP2 was raised against the synthetic peptide SFLLRNPNDKYEPF as described previously. ${ }^{8}$ This peptide corresponds to residues 42 to 55 of the human thrombin receptor C-terminal to the site of cleavage by thrombin. The epitope for this antibody is retained following receptor cleavage by thrombin. Sections were incubated with blocking serum, followed by ATAP2 (0.4 $\mathrm{mg} \mathrm{ml}^{-1}$ ) for one hour at room temperature, and then stained using a Vectastain Elite avidin-biotin-peroxidase kit (Vector Labs, UK). The peroxidase product was visualized with 3,3'-diaminobenzidine tetrahydrochloride (DAB) and enhanced by the glucose oxidase-nickel-DAB technique. ${ }^{9}$ Alternatively, some sections were stained using fluorescein isothiocyanate (FITC) conjugated $\mathrm{F}\left(\mathrm{ab}^{\prime}\right)_{2}$ fragments of rabbit anti-mouse immunoglobulin (Dako, UK). Sections stained by the avidinbiotin method were dehydrated, cleared, and mounted in DPX (BDH, UK). Sections used for immunofluorescence were mounted in glycerol-phosphate buffered saline $(9: 1)$.

Where sections were double stained for thrombin receptors and non-specific esterase, 


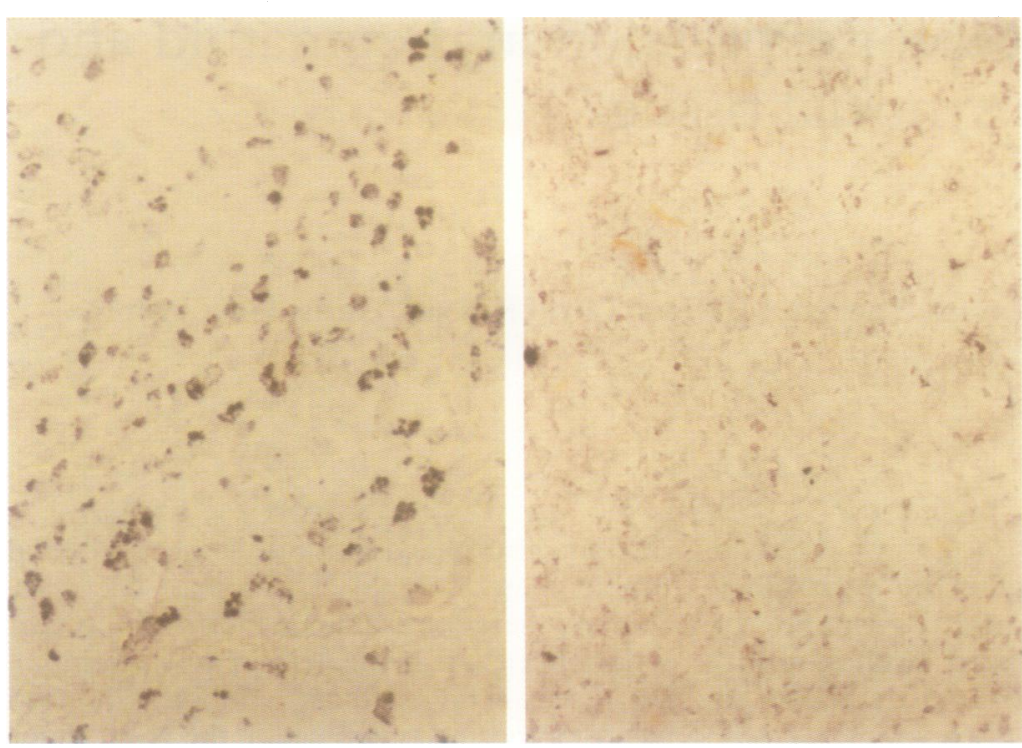

Figure 1 Staining of synovial membrane frozen section for thrombin receptors (ATAP 2). Numerous cells stain positively (dark purple) in rheumatoid arthritis (left) but few in osteoarthritis (right). $\times 144$

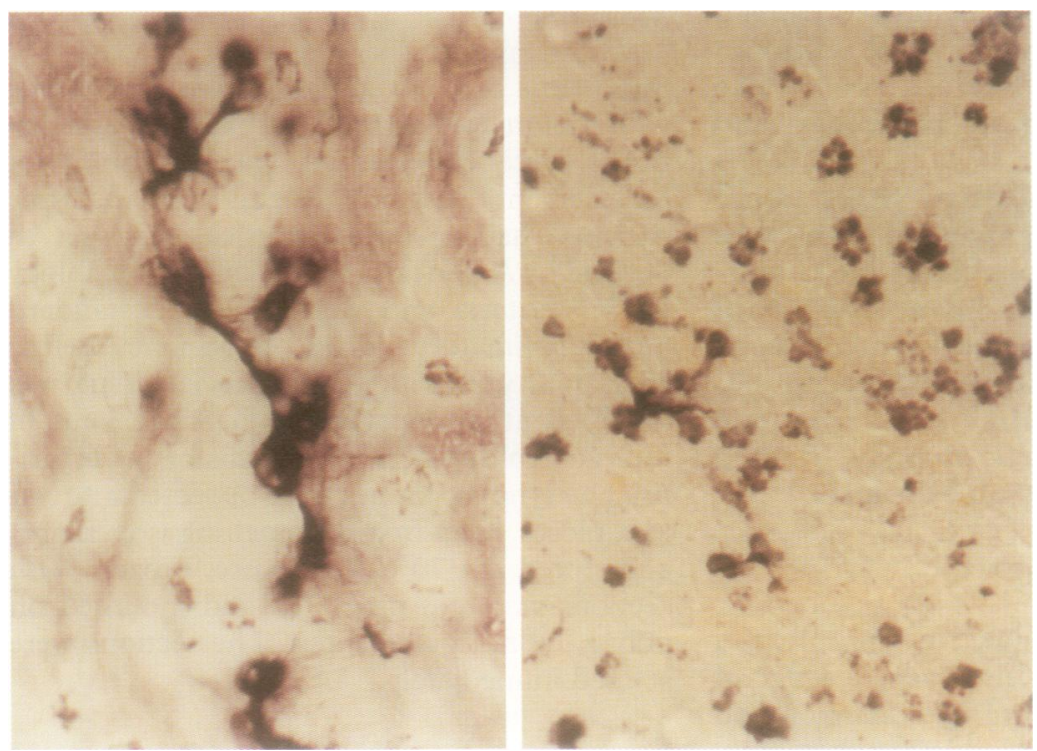

Figure 2 ATAP 2-positive cells in rheumatoid arthritis synovial intima showing linear, interconnected, stellate morphology (left), $\times 570$. Subintimal cells with a rounded granular appearance (right), $\times 433$. subintimal tissues; many of these cells formed interconnected groups, often arranged linearly (fig 2, left panel); (b) rounded cells in the subintimal tissue, on which the staining had a dotted appearance (fig 2 , right panel). In addition, we observed thrombin receptor expression in some cells within synovial nodular lymphocytic infiltrates (fig 3, left panel). In sections double stained for thrombin receptors and non-specific esterase (fig 3, right panel), ATAP-2 positive synoviocytes staining both positively (macrophage-like) and negatively (fibroblast-like) for esterase were present. No staining was observed in sections where the primary antibody had either been omitted or preabsorbed with the immunising peptide.

\section{Discussion}

Our results provide the first evidence that thrombin receptors are expressed by cells within the rheumatoid synovium. Strong staining of receptors was evident on non-specific esterase positive synovial macrophages, supporting previous work by Nelken et al. ${ }^{11}$ These investigators detected thrombin receptors on both alveolar macrophages and macrophages in atherosclerotic plaques. It is not known if upregulation of thrombin receptor expression is common to all inflammatory diseases but it seems likely that receptor expression would be a natural consequence of exposure to plasma thrombin extravasated during the inflammatory response. However, the presence of receptor positive cells throughout the rheumatoid synovium, and not just in association with vessels, suggests that the enzyme may play a role in disease pathogenesis. For example, thrombin upregulates expression of P-selectin, ${ }^{12}$ an adhesion molecule that is probably important in regulating monocyte adhesion to the vasculature in rheumatoid arthritis. ${ }^{13}$ We have recently shown that a single low dose of thrombin induces a prolonged inflammatory response when injected intra-articularly into the rat knee joint. ${ }^{14}$

Mitogenesis of fibroblasts is also thought to be stimulated through the thrombin receptor, ${ }^{2}$ suggesting that thrombin may be involved in the proliferation of synovial fibroblast-like cells. We had previously presented evidence that this occurred in the inflamed synovium, ${ }^{15} \mathrm{a}$ conclusion confirmed by a recent study using antibodies to specific markers of cell proliferation. ${ }^{16}$ In addition, our observation that thrombin receptors are present on cells within synovial lymphocytic infiltrates agrees with the findings of Howells $e t$ al. ${ }^{17}$ This group detected thrombin receptors on certain subpopulations of peripheral blood lymphocytes. The importance of such observations with respect to rheumatoid arthritis is unclear, but they suggest that thrombin could play a part in immune mediated functions such as macrophage activation. The proinflammatory and mitogenic effects of thrombin are probably beneficial after injury, stimulating inflammation and subsequent healing, but inappropriate in chronic inflammation as exemplified by the rheumatoid joint. right panel). Positive staining of cells appeared to follow two patterns: (a) intensely stained cells with stellate morphology, scattered within the synovial intimal layer and throughout 

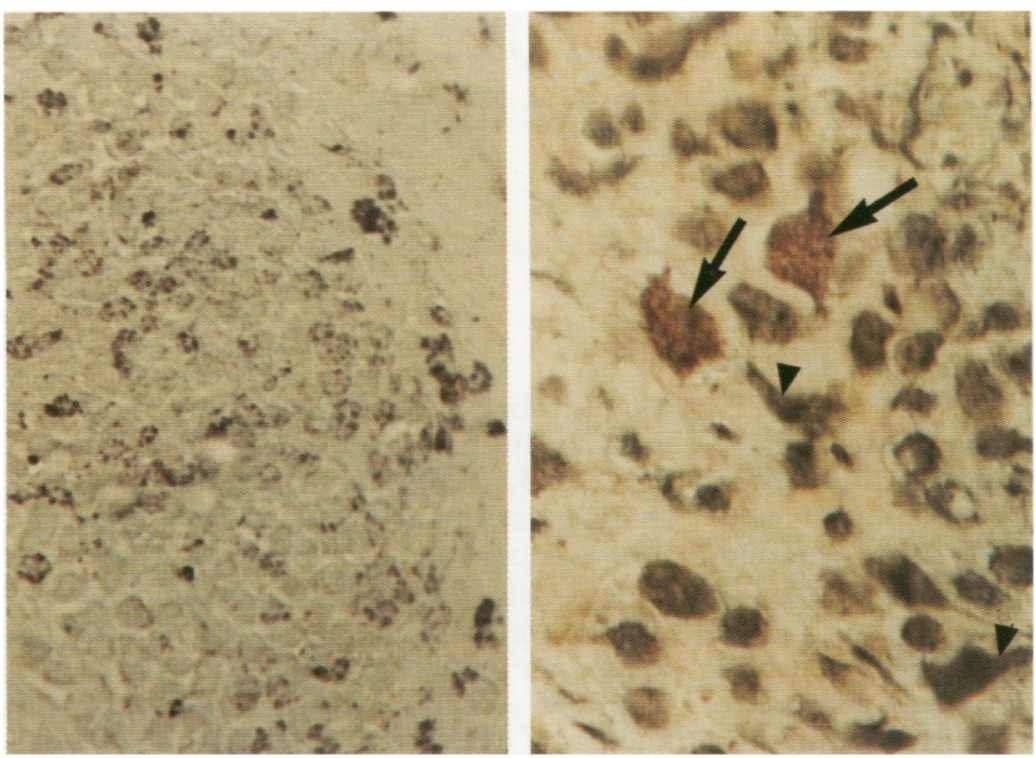

Figure 3 Thrombin receptor expression in scattered cells within a nodular lymphocytic infiltrate in rheumatoid arthritis (right). Double staining of synovial membrane for ATAP 2 (purple) and non-specific esterase (pink) (left). Some ATAP-2 positive macrophage-like synoviocytes are also positive for esterase (arrows). Fibroblast-like synovocytes positive for $A T A P-2$, are negative for esterase (arrow heads), $\times 443$. Supported by grants from the Medical Research Council and
The Wellcome Trust (RM), NIH RO1-HLA9987 (LFB), and The Arthritis and Rheumatism Council for Research (CJM, DRe A

1 Bar-Shavit R, Kahn A, Wilner GD, Fenton JW. Monocyte chemotaxis: stimulation by specific exosite region in thrombin. Science 1983;220:728-31.

2 Chen LB, Buchanan JM. Mitogenic activity of blood components I: thrombin and prothrombin. Proc Natl Acad Sci USA 1975;72:131-5.

3 Laposta M, Dovnarsky DK, Shin HS. Thrombin-induced gap formation in confluent endothelial cell monolayers in vitro. Blood 1983;62:549-56.
4 Vu T-KH, Hung DT, Wheaton VI, Couglin SR. Molecular cloning of a functional thrombin receptor reveals a novel proteolytic mechanism of receptor activation. Cell 1991; 64:1057-68.

5 Hung DT, Vu T-KH, Nelken NA, Coughlin SR. Thrombininduced events in non-platelet cells are mediated by the unique proteolytic mechanism established for the cloned
platelet thrombin receptor. $f$ Cell Biol 1992;116:827-32.

6 Weinberg JB, Pippen AMM, Greenberg CS. Extravascular fibrin formation and dissolution in synovial tissue of patients with osteoarthritis and rheumatoid arthritis. Arthritis Rheum 1991;34:996-1005.

7 Lindahl U, Pejler G, Bogwald J, Seljelid R. A prothrombinase complex of mouse peritoneal macrophages. Arch Biochem Biophys 1989;273:180-8.

8 Brass LF, Vassallo RR, Belmonte E, Ahuja M, Cichowski K, Hoxie JA. Structure and function of the human platelet thrombin receptor. $\mathcal{F}$ Biol Chem 1992;267:13795-8.

9 Shu S, Ju G, Fan L. The glucose oxidase DAB nickel method in peroxidase histochemistry of the nervous system. Neurosci Lett 1988;85:169-71.

10 Gomori G. Histochemistry of human esterases. $f$ Histochem Cytochem 1955;3:479-94.

11 Nelken NA, Soifer SJ, O'Keefe J, Vu T-KH, Charo IF, Coughlin SR. Thrombin receptor expression in norma and atherosclerotic human arteries. $\mathcal{F}$ Clin Invest 1992; 90:1614-21.

12 Sugama Y, Tiruppathi C, Janakidevi K, Andersen TT, Fenton JW, Malik AB. Thrombin-induced expression of endothelial P-selectin and intercellular adhesion molecule-1: a mechanism for stabilising neutrophil adhesion. $\mathcal{F}$ Cell Biol 1992;119:935-44.

13 Grober JS, Bowen BL, Ebling H, Athey B, Thompson CB, Fox DA, et al. Monocyte-endothelial adhesion in chronic rheumatoid arthritis. $\mathcal{f}$ Clin Invest 1993;91:2609-19.

14 Morris R, Winyard PG, Blake DR, Morris CJ. Thrombin in inflammation and healing: relevence to rheumatoid arthritis. Ann Rheum Dis 1994;53:72-9.

15 Morris CJ, Blake DR, Wainwright AC, Steven MM. The relationship between iron deposits and tissue damage in the synovium-an ultrastructural study. Ann Rheum Dis 1986;45:21-6.

$16 \mathrm{Qu} \mathrm{Z,} \mathrm{Garcia} \mathrm{CH,} \mathrm{O'Rourke} \mathrm{LM,} \mathrm{Planck} \mathrm{SR,} \mathrm{Kohli} \mathrm{M,}$ Rosenbaum JT. Local proliferation of fibroblast-like synoviocytes contributes to synovial hyperplasia. Arthritis Rheum 1994;37:212-20.

17 Howells GL, Macey M, Curtis MA, Stone SR. Peripheral blood lymphocytes express the platelet-type thrombin receptor. Br $\mathcal{F}$ Haematol 1993;84:156-60. 